\title{
Accountability for the human right to health through treaty monitoring: Human rights treaty bodies and the influence of concluding observations
}

\author{
Benjamin Mason Meier, Marlous De Milliano, Averi Chakrabarti and Yuna Kim \\ Department of Public Policy \& Department of Health Policy and Management, University of North Carolina at Chapel \\ Hill, Chapel Hill, NC, USA
}

\begin{abstract}
Employing novel coding methods to evaluate human rights monitoring, this article examines the influence of United Nations (UN) treaty bodies on national implementation of the human right to health. The advancement of the right to health in the UN human rights system has shifted over the past 20 years from the development of norms under international law to the implementation of those norms through national policy. Facilitating accountability for this rights-based policy implementation under the right to health, the UN Committee on Economic, Social and Cultural Rights (CESCR) monitors state implementation by reviewing periodic reports from state parties, engaging in formal sessions of 'constructive dialogue' with state representatives, and issuing concluding observations for state response. These concluding observations recognise the positive steps taken by states and highlight the principal areas of CESCR concern, providing recommendations for implementing human rights and detailing issues to be addressed in the next state report. Through analytic coding of the normative indicators of the right to health in both state reports and concluding observations, this article provides an empirical basis to understand the policy effects of the CESCR monitoring process on state implementation of the right to health.
\end{abstract}

\section{ARTICLE HISTORY}

Received 4 April 2017

Accepted 10 October 2017

\section{KEYWORDS}

Right to health; human rights monitoring; Committee on Economic, Social and Cultural Rights; United Nations; accountability

\section{Introduction}

Where the United Nations (UN) seeks to facilitate international accountability for national policy, this article examines UN efforts to monitor state implementation of the human right to health through the UN Committee on Economic, Social and Cultural Rights (CESCR). Examining the CESCR's concluding observations, which recognise the positive steps taken by states and highlight the principal areas of Committee concern, these concluding observations provide recommendations for the implementation of the right to health and outline issues to be addressed in the next state report. This article analyses correlations between the normative indicators of the right to health that are raised in the CESCR's concluding observations and the corresponding indicators that are raised in subsequent state reports.

The human right to health has been firmly established under international law, evolving since the birth of the UN to encompass normative attributes and principles over a wide range of determinants of health. Yet, despite an expansion of state support for the obligations of the right to health - evidenced by a steady increase in state ratification of the International Covenant on 
Economic, Social and Cultural Rights (ICESCR) - studies have continued to show an ambiguous relationship between treaty ratification and human rights implementation. International treaty monitoring is seen as a principal mechanism to facilitate accountability for the implementation of the human right to health, with treaty bodies monitoring implementation by reviewing periodic reports from state parties, engaging in formal sessions of 'constructive dialogue' with state representatives, and issuing concluding observations for state response. With states authorising UN treaty bodies under international law, providing a mandate for international monitoring, such monitoring seeks to provide legal accountability for state implementation in the absence of a global judiciary, overcoming an 'enforcement problem' in human rights through state reporting and international assessment.

This article examines CESCR monitoring of state practices to implement the right to health. The background describes human rights treaty monitoring for the right to health, outlining the development of the right to health under international law and elaborating the processes through which the CESCR monitors state implementation of health obligations. To investigate these monitoring processes, this article then reviews the analytic coding methods by which this study researched indicators of the right to health in both state reports and CESCR concluding observations. Analysing associations between concluding observations and subsequent state reports, the results - examining indicators of both public health topics and human rights norms - provide empirical assessment of the influence of treaty monitoring on implementation of the right to health. The discussion assesses continuing deficiencies in this monitoring process, considering indicatorbased reporting and public health data as a basis to facilitate accountability for human rights implementation.

\section{Background}

As a basis for global justice under international law, human rights stands as a central normative framework for global health, offering universal standards by which to frame government responsibilities and facilitate legal accountability (Gruskin, 2012). Following from the evolving development of the right to health over the past 70 years, the UN human rights system has shifted from the development of human rights under international law to the implementation of those rights through national policy (Hunt, 2017). Accountability for this national implementation may be facilitated through international monitoring, with the CESCR leading UN human rights treaty bodies in monitoring state obligations under the right to health (Meier \& Brás Gomes, forthcoming).

\section{Right to health}

With the 1946 Constitution of the World Health Organisation (WHO) serving as the first international treaty to conceptualise a human right to health, states declared that 'the enjoyment of the highest attainable standard of health is one of the fundamental rights of every human being', defining health positively to include 'a state of complete physical, mental, and social well-being and not merely the absence of disease or infirmity' (WHO, 1946, preamble). Drawing on the WHO Constitution, the UN General Assembly adopted the 1948 Universal Declaration of Human Rights (UDHR), including in it a set of interrelated rights to medical care and underlying determinants of health:

Everyone has the right to a standard of living adequate for the health and well-being of himself and of his family, including food, clothing, housing and medical care and necessary social services ... (UN General Assembly, 1948, art. 25).

From this birth of human rights for global health, the UN human rights system has sought to develop the right to health under international law, with human rights now addressing public health through an expansive and reinforcing set of international treaties and global standards (Yamin, 2005). 
The 1966 ICESCR has provided seminal codification of this right under international treaty law, framing government obligations to progressively realise 'the right of everyone to the enjoyment of the highest attainable standard of physical and mental health' (UN General Assembly, 1966, art. 12). Elaborating the normative content of this evolving right, the CESCR - the UN treaty body charged with both interpreting and monitoring the ICESCR - issued a General Comment in 2000 to provide authoritative interpretation of the normative attributes and principles of the human right to health (CESCR, 2000). In finding that there exist legal obligations to address 'underlying determinants of health', the Committee clarified in General Comment 14 that the right to health depends on a wide range of interconnected rights - beginning in preventive and curative care and expansively encompassing underlying rights to food, housing, work, education, equality, privacy and information (CESCR, 2000, p. 11). This human rights focus on determinants of health has since been extended by the UN Special Rapporteurs on the Right to Health, WHO Commission on Social Determinants of Health and UN General Assembly - moving toward a rights-based 'health-in-all-policies' approach under the Sustainable Development Goals (SDGs) (Hawkes \& Buse, 2016).

Operationalising these human rights obligations, policymakers have sought to move from the development of health-related rights under international law to the implementation of these normative standards in national policy (UN, 2005). This implementation process, from the acceptance of international norms to the improvement of individual lives, does not occur automatically and is contingent on a long chain of programmatic steps, necessitating examination of national reforms at each stage of human rights implementation (Getgen \& Meier, 2009). With human rights law framing national implementation efforts for underlying determinants of health, it is necessary to facilitate accountability for this implementation through, inter alia, advocacy, litigation and monitoring at the national, regional and international levels (Yamin, 2008).

\section{Accountability through monitoring}

Human rights treaty bodies, given an explicit mandate to assess human rights treaty implementation, have become leading institutions of international monitoring (Bayefsky, 2001). In addition to interpreting human rights norms (through general comments, recommendations and statements), treaty bodies hold international legal authority to monitor national efforts to implement treaty obligations (Egan, 2011). Where the treaty monitoring process was long criticised for its procedural inefficiencies - including the absence, lateness or unsatisfactory content of state reporting - the UN has sought to streamline the treaty monitoring process in assessing state implementation of human rights (OHCHR, 2012a). Providing an external check on state efforts to implement human rights obligations, this international monitoring assists states in assessing achievements and recommending reforms (Mechlem, 2009), seeking to facilitate accountability for the progressive realisation of the human right to health (Forman, Caraoshi, Chapman, \& Lamprea, 2016).

Treaty bodies monitor state implementation of human rights treaties through the review of state reports, constructive dialogue with state delegations and concluding observations on state obligations (Figure 1).

Following treaty ratification, states are obligated to submit to the treaty body an initial report about national human rights conditions and thereafter submit periodic reports every 5 years on national efforts to implement treaty obligations (O'Flaherty \& Tsai, 2012). The treaty body considers these state reports in conjunction with information presented by sources independent of the state, including national human rights institutions (NHRIs), non-governmental organisations (NGOs) and civil society, academic institutions and international organisations. These independent reports - referred to as 'stakeholder reports', 'alternative reports' or 'shadow reports' - often challenge the state report by presenting alternative views on state performance. Engaging thereafter in 'constructive dialogue', the state sends a delegation to meet directly with the treaty body - to present the state's report, respond to questions and discuss implementation of treaty obligations (Egan, 2011). 


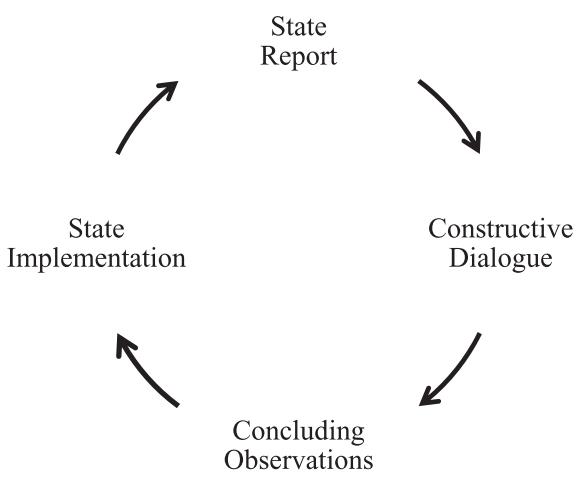

Figure 1. Treaty body monitoring process.

Treaty bodies complete each state assessment by issuing 'concluding observations'. These concluding observations are comprised of sections that assess both 'positive aspects' and 'principle areas of concern' in a state's human rights record. The concluding observations end with recommendations to enhance the implementation of human rights, offering an important interpretive tool for meeting treaty obligations (Connors, 2000; O'Flaherty, 2006). While the issuance of concluding observations brings the formal consideration of a state report to a close, each treaty body employs distinct follow-up procedures in the ensuring years, continuing the process of monitoring state implementation until the next report (Ploton, 2017). With each periodic report building on the concluding observation before it, the process is intended to form a virtuous cycle in each round of monitoring, with these continuing assessments building momentum for the implementation of healthrelated human rights.

\section{Committee on Economic, Social and Cultural Rights}

The CESCR, composed of 18 independent experts, has become the principal human rights treaty body in monitoring state implementation of public health obligations. Operating in tandem with other national, regional and international monitoring institutions - including the Human Rights Council's Universal Periodic Review (UPR) of all human rights - the CESCR monitors the implementation efforts of its 165 states parties on a range of economic, social and cultural rights, facilitating accountability for the seminal right to health obligations that states have assumed by ratifying the ICESCR (Meier \& Brás Gomes, forthcoming). Such external monitoring has particular relevance to the realisation of the ICESCR (Alston, 1987), which obligates a state to take steps only 'to the maximum of its available resources, with a view to achieving progressively the full realisation of the rights' (UN General Assembly, 1966, art. 2). This 'principle of progressive realisation' is a formal recognition that the full realisation of rights will be dependent on financial resources, giving flexibility to states in resource expenditures and necessitating periodic monitoring of progressive implementation efforts (CESCR, 1990).

In structuring state reporting on these implementation efforts every 5 years, the CESCR's 2008 Reporting Guidelines have established an article-by-article reporting process, including specific indicators for each substantive right of the ICESCR (CESCR, 2008). Specifying what states should report on the progressive realisation of the right to health, examining both the extent and pace of human rights realisation, these Reporting Guidelines direct states in describing their progress to: implement the ICESCR, address issues raised in general comments and respond to previous concluding observations (Coomans, 2009). Yet, with only limited efficacy of these Reporting Guidelines in the evolving content of state reporting to the CESCR (Meier \& Kim, 2015), treaty body monitoring mechanisms have not been thoroughly studied to assess their effectiveness in facilitating human rights accountability (Krommendijk, 2015). 


\section{Methodology}

Investigating monitoring mechanisms for the human right to health, this international institutions research examines the extent to which the CESCR's concluding observations are structuring state public health reporting. The authors hypothesised that the CESCR's concluding observations influence subsequent state reports, as measured by the frequency of indicators of the right to health in consecutive state reports and intervening concluding observations. By examining the association between right to health indicators in state reports and previous concluding observations, this study analyses the influence of treaty monitoring on human rights implementation by examining the changing public health information reported to human rights treaty bodies.

\section{Analytic coding}

This study employed analytic coding methods to analyse the content of state reports and concluding observations. Coding allows for the systematic identification of thematic content in a text, providing a means to organise, correlate and analyse themes across a set of documents (Bradley, Curry, \& Devers, 2007). Where qualitative coding methodologies have taken root in the public health policy literature - examining, for example, the impact of public health laws on public health outcomes (Burris et al., 2010) - these empirical methodologies are only beginning to be applied to analyse human rights for global health (Heymann, Cassola, Raub, \& Mishra, 2013).

With a scarcity of cross-national data on human rights practices, this study compiled a dataset of state human rights reports and CESCR concluding observations, coding these documents based upon normative indicators of the human right to health. Although few have studied the contemporary practice of the CESCR, this treaty body provides an unparalleled perspective on human rights treaty monitoring for public health (Potts \& Hunt, 2008). Influential in interpreting state obligations under the right to health, a pilot study confirmed that the CESCR is the human rights treaty body to which states report the vast majority of their public health implementation efforts.

The authors worked with a team of five researchers (the research team) to compile a comprehensive collection of state human rights reports and CESCR concluding observations, beginning with the 164 state reports submitted to the CESCR between 2001 and 2013. To identify thematic changes across periodic reports, the dataset of relevant reports was winnowed to the 38 states that had reported twice in the 13-year timeframe. ${ }^{1}$ In addition to these 76 state reports, the study collected the intervening 38 CESCR concluding observations, allowing for an examination of the influence of concluding observations on subsequent state reports (Figure 2).

These state reports include 15 low- and middle-income and 23 high-income countries (as classified by the World Bank's standards on GNI per capita), allowing for the comparison of countries by relative level of wealth.

To code the documents in this dataset, a codebook was developed to capture indicators of the right to health. Including the public health topics and human rights norms to be examined in each state report and concluding observation, these deductive codes (indicators) reflect topical issues of public health (derived from the WHO classification of health topics) and the following norms of the human right to health (derived from CESCR general comments) (Table 1).

The full codebook included these codes, a brief definition of each code and examples of coded text (MacQueen, McLellan, Kay, \& Milstein, 1998). Three experts at the intersection of global health and human rights reviewed the codebook for its accuracy in capturing right to health indicators, and

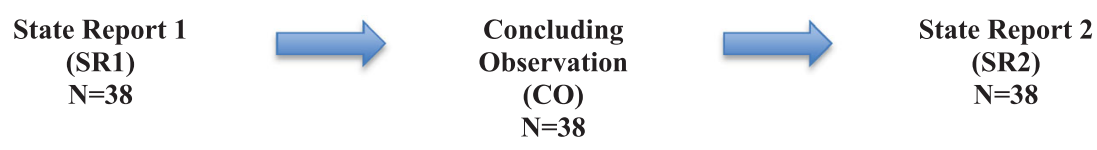

Figure 2. Dataset of state reports and concluding observations. 
Table 1. Normative content of the right to health.

\begin{tabular}{|c|c|c|c|c|c|c|c|}
\hline $\begin{array}{l}\text { Type of } \\
\text { Information }\end{array}$ & $\begin{array}{l}\text { Type of } \\
\text { Obligation }\end{array}$ & $\begin{array}{c}\text { Normative } \\
\text { Attributes (AAAQ) }\end{array}$ & $\begin{array}{l}\text { Human Rights } \\
\text { Principles }\end{array}$ & \multicolumn{2}{|c|}{ Population Addressed } & $\begin{array}{c}\text { Quantitative } \\
\text { or } \\
\text { Qualitative }\end{array}$ & $\begin{array}{c}\text { Committee } \\
\text { Sentiments } \\
\text { (applies only } \\
\text { to } \\
\text { concluding } \\
\text { observations) }\end{array}$ \\
\hline Structure & Respect & $\begin{array}{l}\text { Affordability } \\
\text { (economic } \\
\text { accessibility and } \\
\text { health insurance } \\
\text { coverage) }\end{array}$ & $\begin{array}{l}\text { Equality and } \\
\text { non-discrimination }\end{array}$ & Urban & $\begin{array}{l}\text { Geographic } \\
\text { regions }\end{array}$ & Quantitative & Supportive \\
\hline Process & Protect & Quality & Participation & Rural & $\begin{array}{l}\text { Physically } \\
\text { disabled }\end{array}$ & Qualitative & Critical \\
\hline \multirow[t]{6}{*}{ Outcome } & Fulfil & $\begin{array}{l}\text { Availability } \\
\text { (quantity of } \\
\text { facilities, goods } \\
\text { and services) }\end{array}$ & $\begin{array}{l}\text { Accountability } \\
\text { (includes } \\
\text { monitoring) }\end{array}$ & Women & $\begin{array}{l}\text { Mentally } \\
\text { disabled }\end{array}$ & & Absent \\
\hline & & $\begin{array}{l}\text { Accessibility } \\
\text { (physical } \\
\text { and information } \\
\text { accessibility) }\end{array}$ & Sustainability & Children & $\begin{array}{l}\text { Older } \\
\text { persons }\end{array}$ & & \\
\hline & & $\begin{array}{l}\text { Acceptability } \\
\text { (medical ethics, } \\
\text { gender, culture) }\end{array}$ & & $\begin{array}{c}\text { Racial/ethnic } \\
\text { minorities }\end{array}$ & Prisoners & & \\
\hline & & & & Migrants & $\begin{array}{l}\text { Indigenous } \\
\text { persons }\end{array}$ & & \\
\hline & & & & Refugees & $\begin{array}{l}\text { Sexual } \\
\text { minorities }\end{array}$ & & \\
\hline & & & & Vulnerab & & & \\
\hline
\end{tabular}

additional inductive codes were added as health topics were conceptualised through the coding process.

Using ATLAS.ti (version 7.5), the research team examined the right to health section of each state report (ICESCR article 12) and the entirety of each concluding observation, coding documents at the paragraph level (Friese, 2012). Every set of documents was coded independently by two randomly assigned members of the research team (Heymann, McNeill, \& Raub, 2014), scrutinising each relevant paragraph to assign one or more codes from the codebook (Figure 3).

To assure consistency in coding designations across coders, the research team was trained together on the human rights norms and public health topics and then met with the lead author on a weekly basis to review the coding of documents and consider missing or misapplied codes (Burla et al., 2008). Facilitating a shared understanding of code definitions, any disagreements among research team members were discussed and resolved, adjusting the codebook to reflect revised indicators and recoding previous documents to assure consistent coding (Heymann, McNeill, \& Raub, 2015).

After all of the documents were coded, the authors analysed the frequency with which these coded paragraphs were found in concluding observations and state reports (controlling for the number of paragraphs per report ${ }^{2}$ ). The association in the frequency of codes (per paragraph) between the two consecutive state reports (SR1 and SR2) was analysed alongside the frequency of codes (per paragraph) in the concluding observation (CO), thereby examining the hypothesised effect of the intervening concluding observation (CO) on subsequent state reporting (SR2). 


\section{Coding limitations}

While coding enables the identification and analysis of the thematic content of the right to health, such methods must account for potential biases in the dataset. It has been well documented that many states are not reporting on-time to treaty bodies, ${ }^{3}$ creating a participation bias due to an oversampling of compliant states, and additional research is necessary to understand those states that ratify a human rights treaty but neglect to report to the corresponding human rights treaty body (Hafner-Burton, 2012). In addition, this study hypothesises that the content of state reports is influenced predominantly by previous concluding observations; however, it is possible that state reports could additionally be influenced by unobserved variables, including other treaty body communications, domestic political pressures and civil society advocacy (Morijn, 2011). Finally, while state reporting may chronicle national efforts to implement rights, there are additional methodological concerns that state self-reporting does not necessarily reflect the actual implementation of human rights on the ground, and additional research will be necessary to examine the links between state reporting and government practice (Hafner-Burton \& Tsatsui, 2005). Notwithstanding these limitations, this novel empirical approach demonstrates the potential of human rights monitoring to influence human rights implementation, analyses the influence of treaty body monitoring as a basis for human rights accountability and generates more specific hypotheses for future studies on human rights implementation practices.

\section{Results}

The adoption of concluding observations by a human rights treaty body provides an authoritative assessment of implementation expectations for each human right in a given treaty. As such, the CESCR's concluding observations include assessments of the right to health that are either (a) critical of state implementation, (b) reflective of an absence of specific information in a state report or (c) supportive of state human rights efforts. Given the CESCR's monitoring role, it is not surprising that critical observations on the right to health (including observations critical of a state for failing to provide pertinent data) far outweigh supportive observations, with the Committee far more likely to focus its concluding observations on subjects of concern and recommendations for future implementation efforts (Figure 4).

Where these concluding observations are intended to provide a basis for future state reporting, an examination of associations between concluding observations and subsequent state reports provides an understanding of the CESCR's influence on state implementation efforts - and thereby a basis for analysing the effectiveness of treaty monitoring in facilitating accountability for the right to health. This part analyses these thematic associations between concluding observations and state reports, examining the extent to which the CESCR's concluding observations have influenced state efforts to report specific (a) public health topics and (b) human rights norms under the right to health. ${ }^{4}$

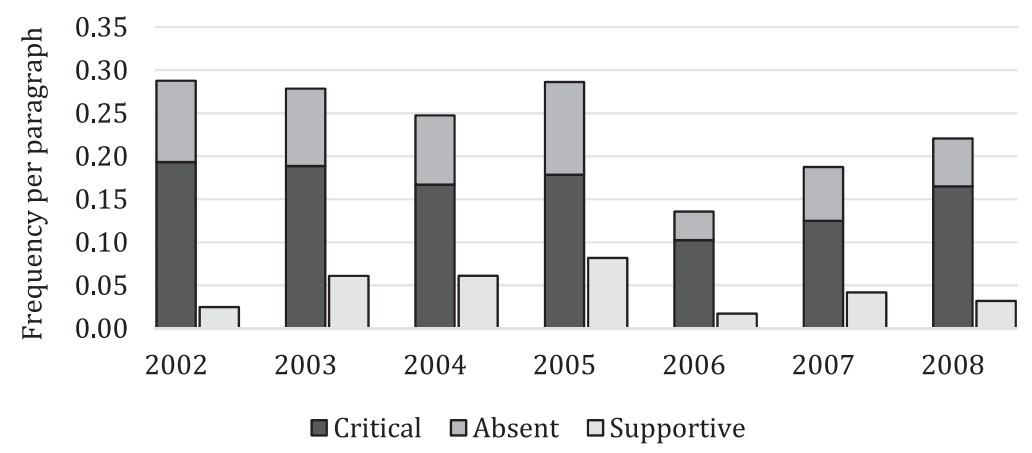

Figure 4. Committee's sentiment in concluding observations. 


\section{Public health topics}

The implementation of the right to health has become a priority for an increasing number of states since General Comment 14, and states have increasingly discussed public health topics in reporting to the CESCR on their implementation efforts (Jung \& Rosevear, 2012) (Figure 5).

The CESCR has addressed a range of public health topics in its concluding observations (Figure 6). Yet, despite increasing evidence of their importance to public health, there are key public health topics to which the CESCR has given negligible attention, including:

- Ageing - which, despite frequent requests for health statistics among 'older persons', does not address the particular health concerns inherent in ageing populations (WHO, 2015).

- Health Research \& Informed Consent - which could indicate a cloistering of discussion on health research before other treaty bodies (Røttingen et al., 2013).

- Public Health Emergencies \& Disaster Relief - which indicates a failure to see health security as relevant to the right to health (Gostin, 2014).

Further, the CESCR has largely neglected intersectional public health issues, avoiding discussion of health in the context of:

- Housing \& Health Facilities;

- Labour \& Occupational Health;

- Environmental Health.
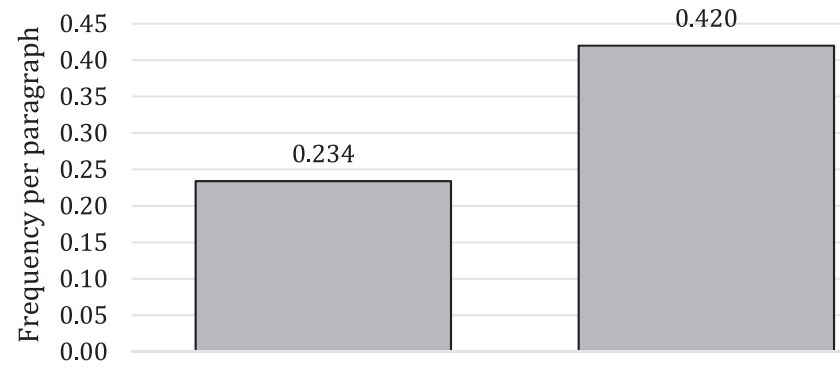

SR1

CO

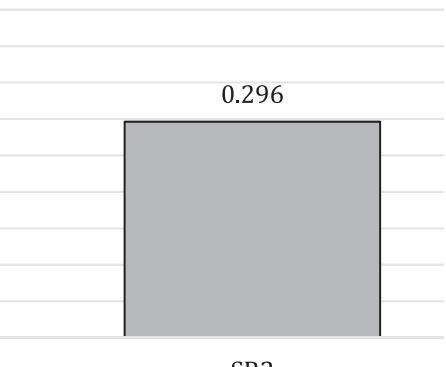

SR2

Figure 5. Average mention of health topics.

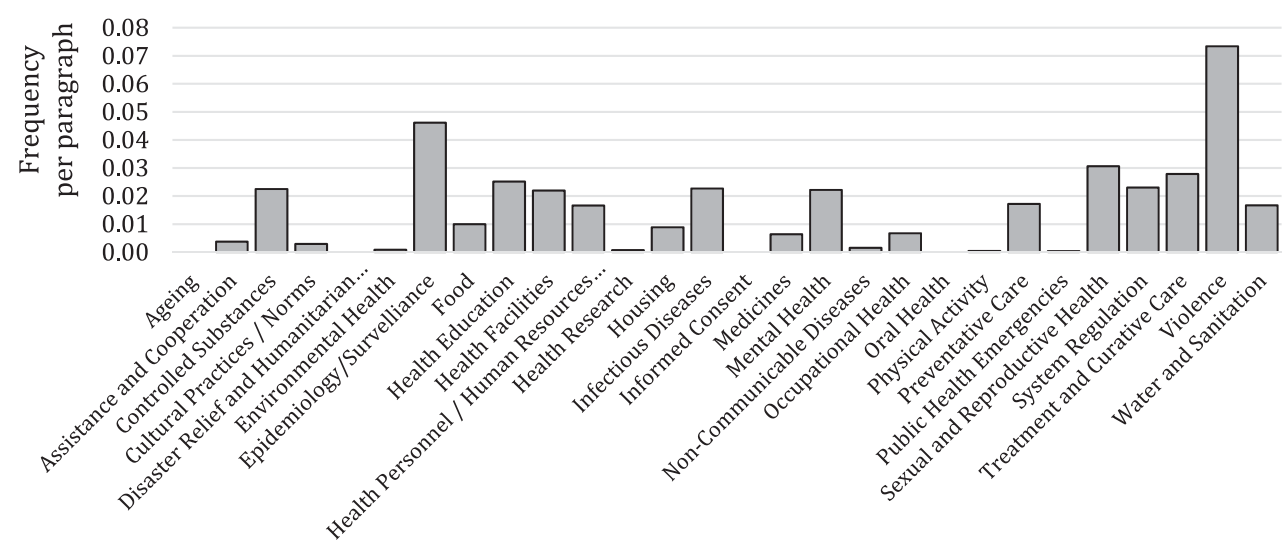

Figure 6. Frequency of public health topics in concluding observations. 
Beyond these gaps in monitoring distal determinants of public health, the CESCR has sought to address the proximal determinants of health raised in General Comment 14 and the Committee's Reporting Guidelines, with these recommendations in concluding observations (often critical of state implementation or noting an absence of specific information) finding mixed effects in subsequent state reports, as seen in the summary of all health topics (Table 2) and the specific health topics that follow.

\section{Medicine versus preventive care}

In accordance with public health discourse, codified in global health policy in the 1978 Declaration of Alma-Ata and translated into obligations of the right to health through General Comment 14 (Meier, 2007), the CESCR has sought to shift states away from medical treatments and toward preventive care in state reporting (Figure 7).

Reflected in the CESCR Reporting Guidelines' holistic emphasis on 'preventive, curative, and rehabilitative health facilities, goods and services', this shift toward preventive care has been observed in the Committee's concluding observations and subsequent state reporting, as seen in:

'The Committee urges the State party to continue its prevention and care efforts in the field of health by providing sexual and reproductive health services to the population, with particular emphasis on those for women, young people and children' (CO Brazil - 2003).

'[A] Program on Health and Prevention in Schools was introduced in 2004 to provide preventive education and to orient young people, teachers, parents, and communities, with a view to reducing the rate of infection of young people in the 13-24 age bracket with HIV and other sexually transmissible diseases. In addition to disseminating sexual and reproductive health concepts among students, the program is aimed at widening the debate about issues related to human rights, gender, discrimination and prejudice, pregnancy, violence, and drugs, as well as providing ongoing training of teachers and health professionals' (SR Brazil, 2007).

The CESCR has proven effective in pushing states toward implementing the right to health through preventive care, even as states have been hard-pressed to provide data on the outcomes of these preventive efforts.

\section{Infectious versus non-communicable disease}

Although global health governance has increasingly focused on non-communicable diseases (NCDs) (Beaglehole et al., 2011; Huckel Schneider, Gillespie, \& Thow, 2017), which have rapidly overtaken infectious disease in morbidity and mortality and recently become an issue of human rights concern (Ferguson, Tarantola, Hoffman, \& Gruskin, 2017), this attention has not translated into state reporting or concluding observations (Figure 8).

When the CESCR has addressed any NCD harms, it has been confined to specific determinants raised in the CESCR Reporting Guidelines - 'the abuse of alcohol and tobacco, and the use of illicit drugs and other harmful substances' (CESCR, 2008) - as seen where:

The Committee recommends that the State party educate young people about the risks of drug abuse and of tobacco and alcohol consumption, to intensify its campaigns against such abuse and excessive consumption, as well as its information campaigns for children, parents, teachers and the general public, and to ensure that adequate counselling services are available to all persons affected by drug, tobacco or alcohol addiction (CO Austria, 2006).

This limited focus on NCDs has neglected necessary policy efforts to address the social determinants of obesity and the attendant pathologies of diabetes, hypertension and cardiovascular disease (Popkin, Adair, \& Ng, 2012). Given that the Committee has given only negligible attention to NCDs in its concluding observations, with the Reporting Guidelines focussing on measures to implement 'strategies of infectious disease control', it is not surprising that this lack of attention is reflected in a relative decrease in states' already paltry attention to these expanding harms. 
Table 2. Trends across state reports following 'critical or absent' sentiment in concluding observations. ${ }^{\text {a }}$

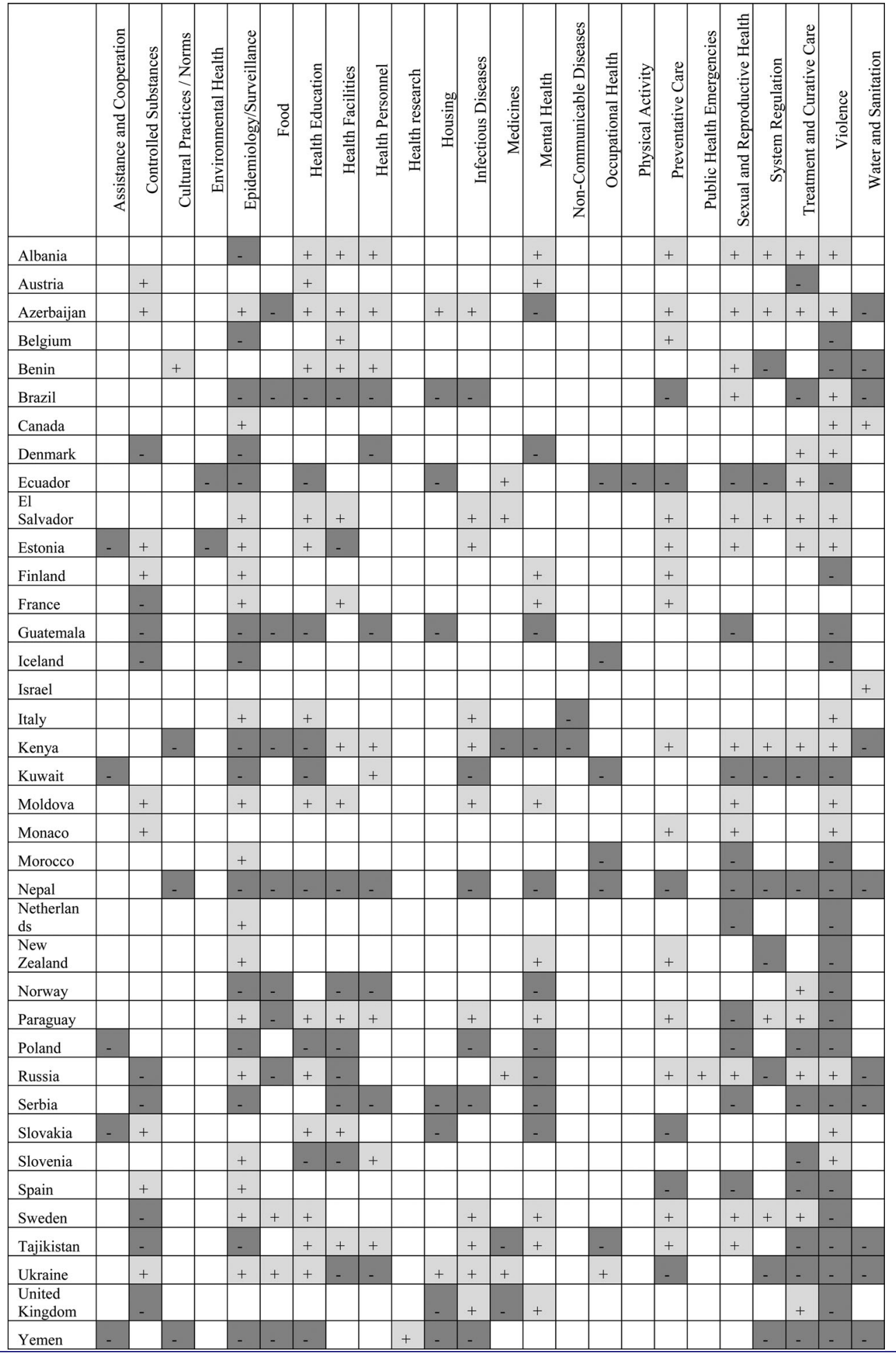

${ }^{\mathrm{a} A}$ positive relationship between reporting trends within state reports and the sentiment expressed by the CESCR implies that the reporting state addressed a given health topic more often than in the previously submitted state report after the CESCR has made critical comments or noted that information was absent on the given health topic. A negative association shows that the country has paid less attention to a given health topic after the CESCR has made critical or absent remarks about it. 


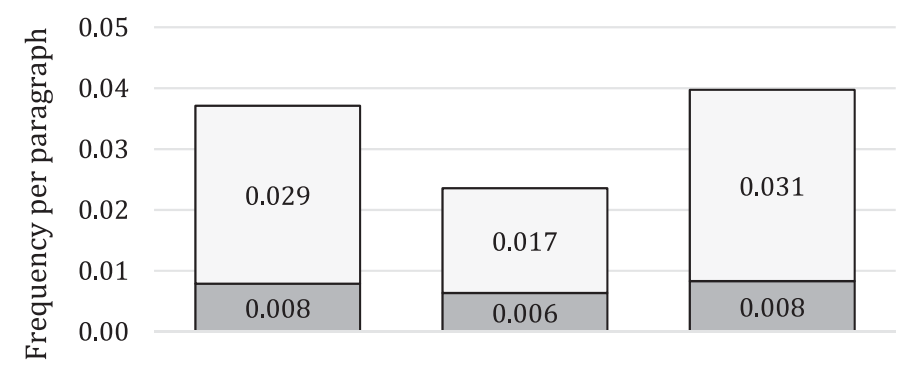

$\square$ Medicines $\quad \square$ Preventative Care

Figure 7. Frequency of medicines and preventative care.

\section{Human resources for health}

Human resources are necessary to assure health service coverage to meet public health challenges (Campbell et al., 2013). Seeking a more equitable distribution of the global health workforce, health education provides the skills essential for health professionals to address changing health needs (Crisp \& Chen, 2014), with the CESCR Reporting Guidelines requesting reporting on measures to ensure 'adequate training of health personnel' (CESCR, 2008). Nevertheless, despite strong CESCR focus on trained health workers in concluding observations, especially in recommending measures to developing countries, there has been little attention to these issues among states (Figure 9).

The Committee has repeatedly drawn attention to the lack of human resources for health in the developing world. When the Committee mentions human resources in its concluding observations, it mentions it together with health education $35 \%$ of the time, as seen in:

The Committee is concerned about the high maternal, infant and under-five mortality rates, the lack of adequately equipped maternal health care facilities and skilled birth attendance, especially in the North Eastern and Coastal Provinces, and de facto discrimination against poor women, older women and women with HIV/AIDS in access to maternal health care (art. 12) (CO Kenya, 2008).

Inapposite to this attention, only high-income states have responded by raising this issue in subsequent reporting on the right to health, as seen in:

The Swedish Government appropriated special funding for 2013 and 2014 to develop course activities for a physician's postgraduate clinical training to become a specialist, which is expected to have a positive impact on the supply of specialists. Among other things, a project has been commissioned to develop and strengthen courses for qualifying physicians as specialists in general psychiatry, as this is a specialty within which there has been a shortage of specialists for some time (SR Sweden, 2013).

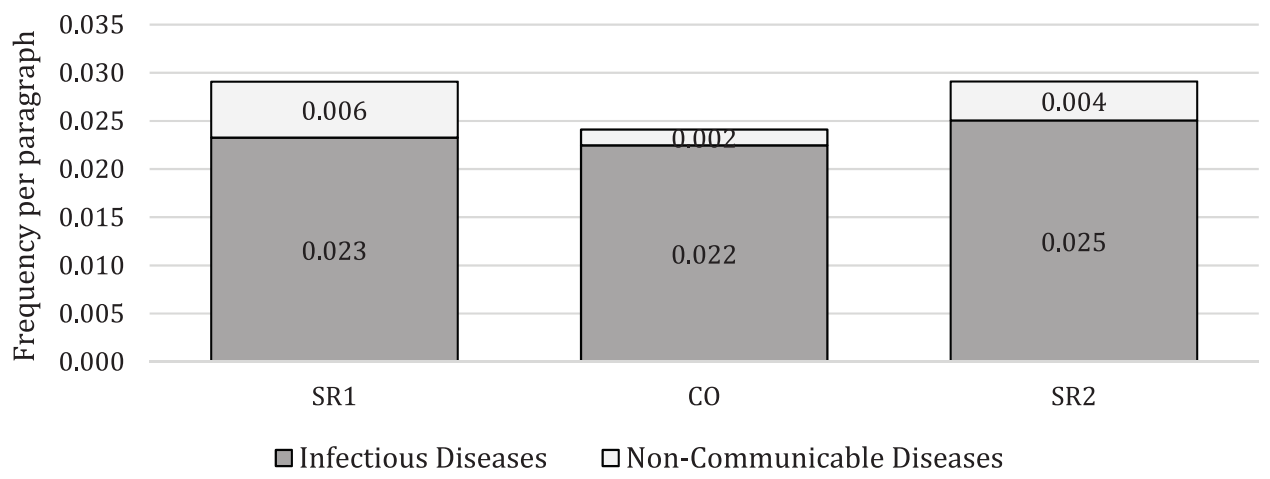

Figure 8. Frequency of infectious diseases and NCDs. 


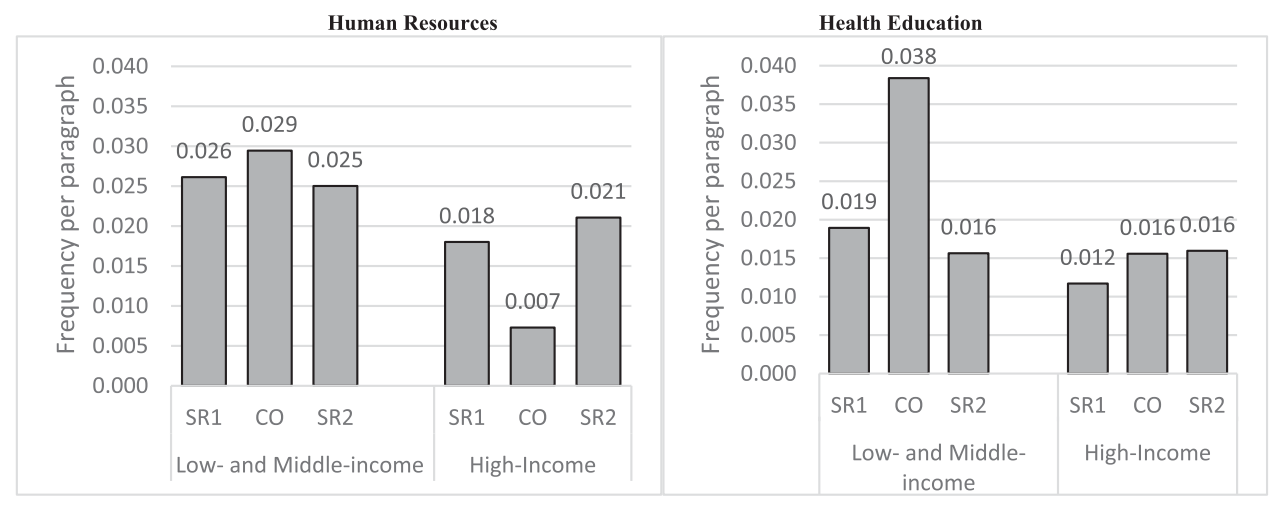

Figure 9. Frequency of human resources and health education.

Without effective monitoring of human resources for health, it is unlikely that states will undertake essential policy reforms to build the health workforce necessary to realise the right to health.

\section{Mental health}

Mental health has long been approached as central to the right to health - if not part of its core content (Gable \& Gostin, 2009). As a result, the CESCR has addressed mental health frequently in concluding observations; however, the effect of this attention is seen only in subsequent reports from low- and middle-income states (Figure 10).

Although the CESCR Reporting Guidelines limit focus on mental health to reporting on measures to 'ensure adequate treatment and care in psychiatric facilities for mental health patients', the CESCR has gone beyond this focus on mental health facilities, as seen in concluding observations and subsequent state reporting:

The Committee encourages the State party to consider alternative forms of mental health treatment, including outpatient treatment (CO Albania, 2008).

Pursuant to the legal frame, the mental health reform continues, aimed at reducing the number of beds in the psychiatric hospitals and the opening of daily community centers for mental health in the districts with psychiatric hospitals and cabinets, as well as in opening protected homes for chronic patients. This reform is designed to observe their rights, improve the living conditions and rehabilitate them to return to their families (SR Albania, 2010).

Highlighting the ability of the CESCR to move beyond its Reporting Guidelines, this monitoring focus on inclusion, non-discrimination and community-based rehabilitation matches public health evidence and reflects a disability rights approach to health (Perlin, 2012).

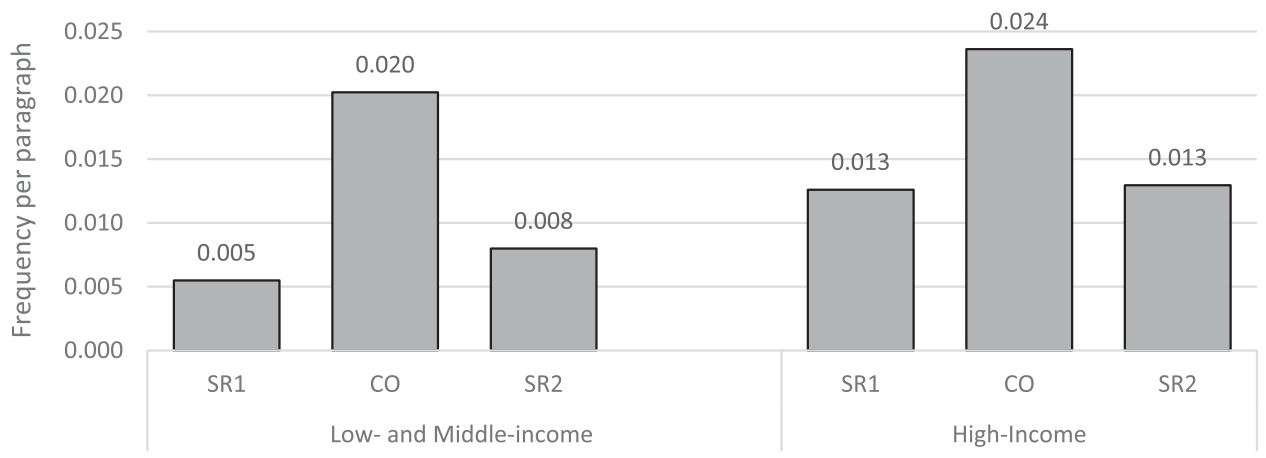

Figure 10. Frequency of mental health by development status. 


\section{Human rights norms}

As part of a rights-based approach to health, the right to health has distinct normative attributes and principles that can be identified, delineated and examined in state efforts to implement the ICESCR and state reporting to the CESCR (Hunt, 2016). However, when compared with public health topics - where the focus on health increases in the second reporting cycle (often in correlation with the themes raised in the previous concluding observation) - there has been far less change in human rights norms over time.

\section{Normative attributes}

Where the CESCR's General Comment 14 introduced an AAAQ indicator framework (focused on availability, accessibility, acceptability and quality) for the right to health, future general comments expanded this focus to account for affordability (as derived from 'economic accessibility'), delineating normative attributes for health wherein:

- Availability refers to a sufficient quantity of underlying determinants of health, public health, and healthcare facilities, goods and services, as well as programmes (CESCR, 2000);

- Accessibility refers to obligations of physical and informational access, including that '[h]ealth facilities, goods and services must be within safe physical reach for all sections of the population' (WHO, 2002);

- Acceptability refers to respect for 'the culture of individuals, minorities, peoples and communities, sensitive to gender and life-cycle requirements, as well as being designed to respect confidentiality and improve the health status of those concerned' (CESCR, 2000);

- Affordability refers to 'ability to pay for services without financial hardship'. Influenced by the health financing system and household income, it 'takes into account not only the price of the health services but also indirect and opportunity costs' (Evans, Hsu, \& Boerma, 2013);

- Quality refers to medically appropriate facilities, goods/services, and programmes, including 'skilled medical personnel, scientifically approved and unexpired drugs and hospital equipment, safe and potable water, and adequate sanitation' (CESCR, 2000).

In the decade following the adoption of General Comment 14, however, an examination of state reports supports early fears that this approach lacked definition in framing the progressive realisation of the right to health (Figure 11). Although low-, middle- and high-income countries approach these normative attributes with approximately equal frequency, the CESCR is far more critical of these normative attributes when assessing developing countries. As seen in the context of affordability, the CESCR is more than three times as likely to address this issue in the concluding observations of low- and middle-income countries despite increasing inequality (and thus decreasing affordability) in high-income countries (Chapman, 2014).

\section{Type of information}

The types of information reflective of the implementation of human rights are categorised through a specific 'structure-process-outcome' typology, with this framework monitoring the links between policy cause and social effect by examining how outcome measures are correlated with changes in structure and process.

- Structure - reflecting commitment to rights through legal instruments (in the constitution and domestic legislation) necessary for facilitating realisation of rights (Hunt, 2006)

- Process - capturing government conduct (in policies, strategies, programmes, interventions, budgets and activities) to implement state obligations (Rosga \& Satterthwaite, 2009)

- Outcome - measuring results (in individual health and population-level public health data) on the actual enjoyment of rights (OHCHR, 2008). 
Low- and Middle-Income

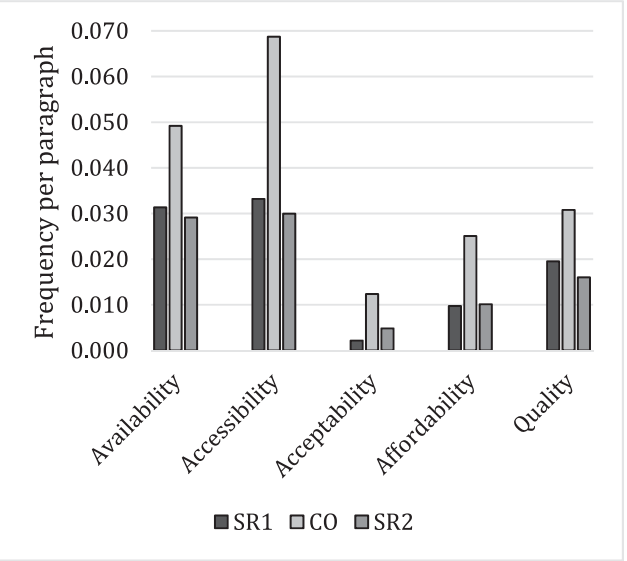

High-Income Countries

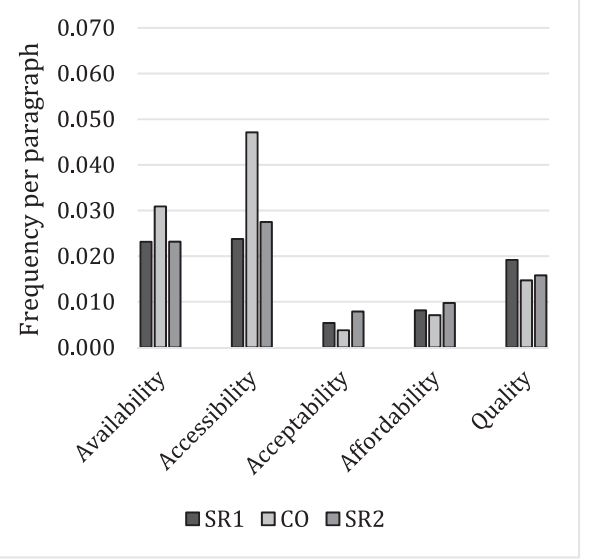

Figure 11. Frequency of normative content by development status.

The UN adopted this tripartite typology to focus states on incremental implementation efforts that could be taken to progressively realise rights and that could be assessed individually by human rights treaty bodies. Recognising that realisation of the right to health depends on legal reforms and resource allocations (WHO, 2017), a focus on outcomes alone provides insufficient information about human rights implementation, and the CESCR has remained committed to monitoring the structures and processes that underlie health outcomes.

This focus in concluding observations has had a dramatic effect on state implementation, with states deemphasising outcomes in subsequent reporting and creating quantitative measures to report on processes relevant to health systems (Table 3). Where the right to health has been incorporated in an increasing number of national constitutions, these new constitutional reforms have supported state efforts to expand quantitative reporting on processes to implement human rights obligations, highlighting the development of new health-related ministries, budgets and policies (Kavanagh, 2016).

\section{Type of obligation}

All human rights are seen to possess three kinds of obligations:

- Respect - refrain from interfering with the enjoyment of the right

- Protect - prevent others from interfering with the enjoyment of the right

- Fulfil - adopt appropriate measures towards the full realisation of the right (CESCR, 2000).

Where the Committee has sought in its concluding observations to focus on state obligations to 'protect' health, states have responded (Figure 12).

The Committee has requested that states take steps to ensure that third parties do not interfere with health (whether through privatised health services, harmful traditional practices or harm to vulnerable populations), and these efforts to protect individuals from non-state actors have led to an increase in state efforts to protect the right to health.

\section{Human rights principles}

Crucial to realising all human rights, the UN has described the 'rights-based approach' to public policy as a means to address fundamental cross-cutting human rights principles for, inter alia, accountability, equality and non-discrimination, and participation (CESCR, 2000). 
Table 3. Co-occurrence between type of information and qualitative/quantitative.

SR1

$\begin{array}{lcc} & \text { Qualitative } & \text { Quantitative } \\ \text { Outcome } & 23.8 \% & 32.3 \% \\ \text { Process } & 16.6 \% & 20.9 \% \\ \text { Structure } & 3.2 \% & 3.2 \%\end{array}$

SR2

$\begin{array}{cc}\text { Qualitative } & \text { Quantitative } \\ 21.2 \% & 31.1 \% \\ 16.6 \% & 24.7 \% \\ 2.9 \% & 3.6 \%\end{array}$

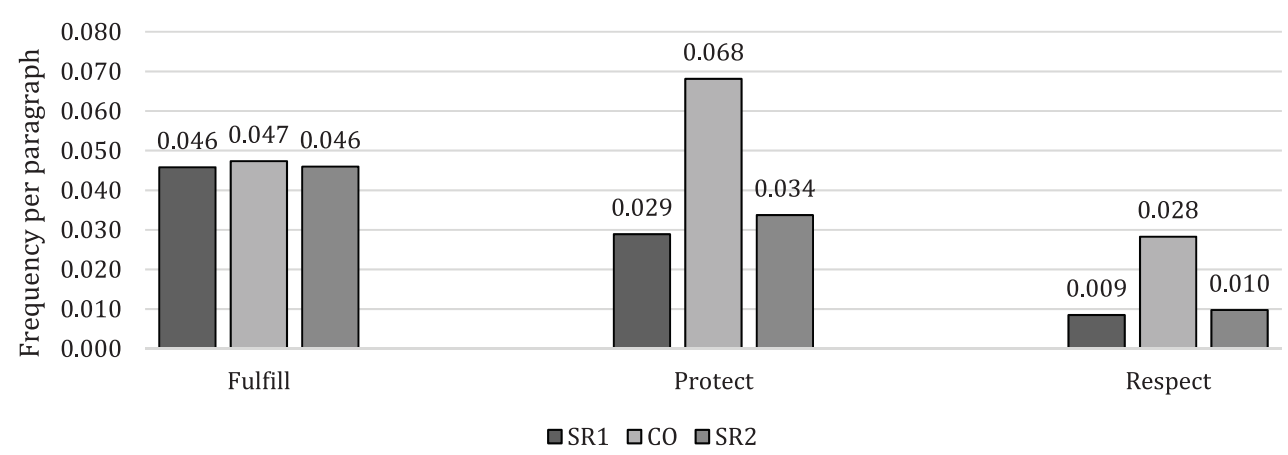

Figure 12. Frequency of type of obligation.

- Accountability - where states must develop domestic monitoring systems to collect accurate data, independent reviews to provide institutional oversight and enforcement mechanisms to ensure corrective action (MacNaughton \& Hunt, 2011)

- Non-discrimination and equality - where the ICESCR prohibits 'discrimination on the grounds of race, colour, sex, age, language, religion, political or health status' (CESCR, 2000)

- Participation - where community members engage in setting the agenda; identifying and selecting policy options and benchmarks; implementing policies and programmes; and monitoring programme effectiveness (Potts \& Hunt, 2009).

These principles pose immediately binding (and often cost-neutral) obligations for the right to health that are not dependent on progressive realisation (Murphy, 2013); yet, states have largely refrained from any discussion of these rights-based principles in their CESCR public health reporting (Figure 13).

To the extent that these cross-cutting principles are seen to apply to the right to health, the CESCR's concluding observations have focused overwhelmingly on equality and non-discrimination; however, despite frequent CESCR discussion of the importance of disaggregated data to address inequality toward marginalised and vulnerable populations (Langford \& King, 2008), states report little information about the inequalities faced by specific populations, limiting the CESCR's ability to recommend affirmative measures to reduce inequality.

\section{Discussion and conclusion}

Human rights treaty bodies are crucial to facilitating accountability for state implementation of the human right to health, but such accountability depends upon state responsiveness to the concluding observations of treaty bodies. With treaty bodies moving toward a 'simplified reporting procedure', framing state reporting solely around the treaty body's 'list of issues' and previous concluding observations (UN General Assembly, 2016), the responsiveness to treaty bodies will become more crucial to state accountability in the years to come. Although state reports are largely responsive to concluding observations, these results raise an imperative for the CESCR to develop more effective monitoring mechanisms to assure implementation of the right to health. For the CESCR to monitor 


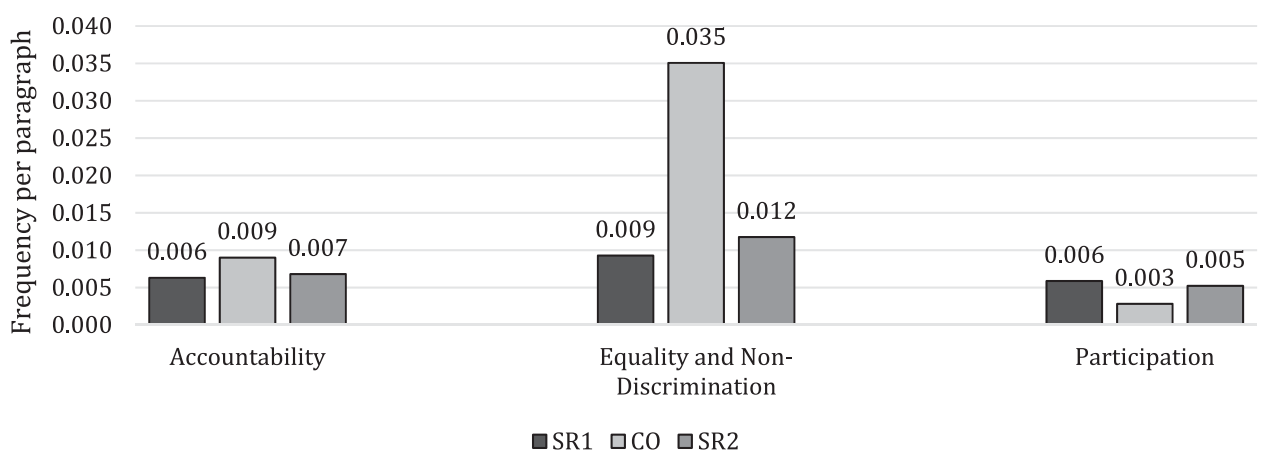

Figure 13. Frequency of human rights principles.

progressive realisation and prevent retrogressive measures in implementing the right to health, there is a need for indicator-based data to assess both public health topics and human rights norms. As part of CESCR efforts to assure that reports meet Committee expectations, revisions of the reporting guidelines could support consistent reporting on those public health data and human rights indicators that reflect the right to health.

Weaknesses of reporting on health topics indicate a need for the CESCR to focus on public health data reflective of realisation of the right to health. As these data are increasingly addressed by public health discourse on social determinants of health (SDH) and universal health coverage (UHC), human rights monitoring requires technical assistance from WHO in providing evidencebased public health information and pertinent health questions to support CESCR monitoring of the right to health (Acharya \& Meier, 2016). In examining the relationship between the right to health and other rights under its ICESCR purview, the CESCR can obtain further information from other UN agencies on underlying determinants of health, recognising the role of the SDGs in framing new intersectoral data collection methods (Hawkes \& Buse, 2016). Where the CESCR views the right to health in isolation, neglecting the interdependence of rights, these intersectional issues raise an imperative for states to move beyond the article-by-article reporting process and for the CESCR to examine data from the interconnected sectors that underlie health.

Beyond the health issues addressed by the CESCR, inadequacy in reporting normative attributes of the right to health reflects a failure to frame consistent human rights indicators for state reporting. For monitoring to facilitate human rights accountability, state reports must present consistent indicators that accurately reflect human rights implementation (OHCHR, 2012b). With states increasingly focusing reporting on structure and process indicators, the CESCR has not linked these commitments and efforts to their associated public health results, neglecting consistent outcome indicators that are essential to assessing the progressive realisation of the right to health over time (Meier \& Kim, 2015). These empirical results, identifying the public health data and human rights norms addressed in CESCR monitoring, can frame the development of universal human rights indicators that could facilitate accountability for the human right to health.

\section{Notes}

1. Although China submitted two reports in this timeframe, this outlier was excluded from the analysis because one of its reports far exceeded the CESCR's guidelines for report length (comprising 1218 paragraphs, compared to an average of 483 paragraphs among all other state reports).

2. The frequency of codes is divided by the number of paragraphs in each of the respective state reports, ensuring comparability across reports where the number of paragraphs differs across countries.

3. Seeking to alleviate this concern for non-reporting states in the years to come, the UN High Commissioner for Human rights recently 'exposed' those states that are delinquent in their reporting to treaty bodies and committed to making this information public. 
4. While this article analyses select associations between concluding observations and state reports, the full dataset of codes for this project can be found at http://bmeier.web.unc.edu/files/2017/04/Right-to-Health_Monitoring_ Dataset_04022017.xlsx, and the authors encourage other researchers to identify additional correlations across right to health indicators that may have been overlooked in the present analysis.

\section{Acknowledgements}

The authors are grateful to: Maria Virginia Brás Gomes, Paul Hunt, Eibe Riedel and Margaret Satterthwaite for their insightful reflections on public health monitoring through human rights treaty bodies; to Neha Acharya, Hunter Baehren, Alison Domonoske, Robert Kohut, Hunter McGuire and Anisha Padma for their dedicated research assistance and yearlong effort to code state reports and concluding observations; and to Jodi Heymann, Scott Burris and Hanna Huffstetler for their thoughtful comments on previous drafts of this article.

\section{Disclosure statement}

No potential conflict of interest was reported by the authors.

\section{References}

Acharya, N., \& Meier, B. M. (2016). Facilitating accountability for the right to health: Mainstreaming WHO participation in human rights monitoring. Health and Human Rights. https://www.hhrjournal.org/2016/04/facilitatingaccountability-for-the-right-to-health-mainstreaming-who-participation-in-human-rights-monitoring/

Alston, P. (1987). Out of the Abyss: The challenges confronting the new U.N. committee on economic, social and cultural rights. Human Rights Quarterly, 9(3), 332-381.

Bayefsky, A. F. (2001). The UN Human Rights Treaty System: Universality at the crossroads. Leiden: Martinus Nijhoff Publishers.

Beaglehole, R., Bonita, R., Horton, R., Adams, C., Alleyne, G., Asaria, P., \& Watt, J. (2011). Priority actions for the noncommunicable disease crisis. The Lancet, 377(9775), 1438-1447.

Bradley, E. H., Curry, L. A., \& Devers, K. J. (2007). Qualitative data analysis for health services research: Developing taxonomy, themes, and theory. Health Services Research, 42(4), 1758-1772.

Burla, L., Knierim, B., Barth, J., Liewald, K., Duetz, M., Abel, T. (2008). From text to codings: Intercoder reliability assessment in qualitative content analysis. Nursing Research, 57, 113-117.

Burris, S., Wagenaar, A. C., Swanson, J., Ibrahim, J. K., Wood, J., \& Mello, M. M. (2010). Making the case for laws that improve health: A framework for public health law research. Milbank Quarterly, 88(2), 169-210.

Campbell, J., Buchan, J., Cometto, G., David, B., Dussault, G., Fogstad, H., ... Tangcharoensathien, V. (2013). Human resources for health and universal health coverage: Fostering equity and effective coverage. Bulletin of the World Health Organization, 91, 853-863.

CESCR. (1990). General comment 3, The Nature of States Parties Obligations, U.N. Doc. E/1991/23.

CESCR. (2000). General comment No. 14, The Substantive Issues Arising in the Implementation of the International Covenant on Economic, Social, and Cultural Rights. U.N. Doc. No. E/C.12/2000/4.

CESCR. (2008). Guidelines on treaty-specific documents to be submitted by states parties under articles 1 and 17 of the International Covenant on Economic, Social and Cultural Rights. U.N. Doc. E/C./12/2008/2.

Chapman, A. R. (2014). The impact of reliance on private sector health services on the right to health. Health and Human Rights, 16, 122-134.

Connors, J. (2000). An analysis and evaluation of the system of state reporting. In A. Bayefsky (Ed.), The UN Human Rights Treaty System in the 21st century (pp. 3-21). The Hague/Boston: Kluwer Law International.

Coomans, F. (2009). The international covenant on economic, social and cultural rights: From stepchild to full member of the human rights family. In F. G. Isa, \& K. de Feyter (Eds.), International human rights law in a global context (pp. 293-317). Bilbao: Universidad de Duesto.

Crisp, N., \& Chen, L. (2014). Global supply of health professionals. New England Journal of Medicine, 370, 950-957.

Egan, S. (2011). The UN Human Rights Treaty System: Law and procedures. Dublin: Bloomsbury.

Evans, D. B., Hsu, J., \& Boerma, T. (2013). Universal health coverage and universal access. Bulletin of the World Health Organization, 91, 546-546A.

Ferguson, L., Tarantola, D., Hoffman, M., \& Gruskin, S. (2017). Non-communicable diseases and human rights: Global synergies, gaps and opportunities. Global Public Health, 12, 1200-1227.

Forman, L., Caraoshi, L., Chapman, A. R., \& Lamprea, E. (2016). Conceptualising minimum core obligations under the right to health: How should we define and implement the 'morality of the depths. The International Journal of Human Rights, 20(4), 531-548.

Friese, S. (2012). Qualitative data analysis with ATLAS.ti. Göttingen: Max Planck Society. 
Gable, L., \& Gostin, L. (2009). Mental health as a human right. In A. Clapsham, \& M. Robinson (Eds.), Realizing the right to health (pp. 249-261). Zurich: Ruffer \& Rub.

Getgen, J. E., \& Meier, B. M. (2009). Ratification of human rights treaties: The beginning, not the end. The Lancet, 374, 447-448.

Gostin, L. (2014). Global health law. Cambridge: Harvard University Press.

Gruskin, S. (2012). Human rights in health systems frameworks: What is there, what is missing and why does it matter? Global Public Health, 7, 337-351.

Hafner-Burton, E. M. (2012). International regimes for human rights. Annual Review of Political Science, 15, $265-286$.

Hafner-Burton, E. M., \& Tsatsui, K. (2005). Human rights in a globalizing world: The paradox of empty promises. American Journal of Sociology, 110, 1373-1411.

Hawkes, S., \& Buse, K. (2016). Searching for the right to health in the sustainable development agenda. International Journal of Health Policy Management, 5(5), 337-339.

Heymann, J., Cassola, A., Raub, A., \& Mishra, L. (2013). Constitutional rights to health, public health and medical care: The status of health protections in 191 countries. Global Public Health, 8(6), 639-665.

Heymann, J., McNeill, K., \& Raub, A. (2014). Assessing compliance with the CRC: Indicators of law and policy in 191 countries. The International Journal of Children's Rights, 22, 425-445.

Heymann, J., McNeill, K., \& Raub, A. (2015). Rights monitoring and assessment using quantitative indicators of law and policy: International covenant on economic, social and cultural rights. Human Rights Quarterly, 37(4), 10711100 .

Huckel Schneider, C., Gillespie, J. A., \& Thow, A. M. (2017). Generating sustained political priority for non-communicable diseases: Towards a suitable governance model. Global Policy. doi:10.1111/1758-5899.12416

Hunt, P. (2006). Report of the special rapporteur on the right of everyone to the enjoyment of the highest attainable standard of physical and mental health, Paul Hunt. UN Economic and Social Council, U.N. Doc. E/CN.4/2006/48.

Hunt, P. (2016). Interpreting the international right to health in a human rights-based approach to health. Health and Human Rights, 18(2), 109-130.

Hunt, P. (2017). Configuring the UN Human Rights System in the "Era of implementation": Mainland and Archipelago. Human Rights Quarterly, 39, 489-538.

Jung, C., \& Rosevear, E. (2012). Economic and social rights across time, regions, and legal traditions: A preliminary analysis of the TIESR dataset. Nordic Journal of Human Rights, 30, 372-394.

Kavanagh, M. M. (2016). The right to health: Institutional effects of constitutional provisions on health outcomes. Studies in Comparative International Development, 51, 328-364.

Krommendijk, J. (2015). The domestic effectiveness of International Human Rights Monitoring in established democracies: The case of the UN Human Rights Treaty Bodies. The Review of International Organizations, 10(4), 489-512.

Langford, M., \& King, J. A. (2008). Committee on economic, social and cultural rights. In M. Langford (Ed.), Social rights jurisprudence: Emerging trends in international and comparative law (pp. 477-516). Cambridge: Cambridge University Press.

MacNaughton, G., \& Hunt, P. (2011). A human rights-based approach to social impact assessment. In F. Vanclay, \& A. M. Esteves (Eds.), New direction in social impact assessment: Conceptual and methodological 355 (pp. 363-365). Cheltenham: Edward Elgar.

MacQueen, K. M., McLellan, E., Kay, K., \& Milstein, B. (1998). Codebook development for team-based qualitative analysis. Cultural Anthropology Methods, 10(2), 31-36.

Mechlem, K. (2009). Treaty bodies and the interpretation of human rights. Vanderbilt Journal of Transnational Law, $42(3), 905$.

Meier, B. M. (2007). Advancing health rights in a globalized world: Responding to globalization through a collective human right to public health. The Journal of Law, Medicine \& Ethics, 35, 545-555.

Meier, B. M., \& Brás Gomes, V. (forthcoming). Human rights treaty bodies: Monitoring, interpreting, and adjudicating health-related human rights. In B. M. Meier, \& L. O. Gostin (Eds.), Human rights in global health: rights-based governance for a globalizing world. New York: Oxford University Press.

Meier, B. M., \& Kim, Y. (2015). Human rights accountability through treaty bodies: Examining human rights treaty monitoring for water and sanitation. Duke Journal of Comparative \& International Law, 26, 141-230.

Morijn, J. (2011). Reforming United Nations Human Rights Treaty monitoring reform. Netherlands International Law Review, 58(3), 295-333.

Murphy, T. (2013). Health and human rights. Portland: Hart Publishing.

O'Flaherty, M. (2006). The concluding observations of United Nations Human Rights Treaty Bodies. Human Rights Law Review, 6, 27.

O'Flaherty, M., \& Tsai, P. (2012). Periodic reporting: The backbone of the UN treaty body review procedures. In M. Cherif Bassiouni, \& W. A. Schabas (Eds.), New challenges for the UN human rights machinery: What future for the UN treaty body system and the Human Rights Council procedures? (pp. 37-56). Cambridge: Intersentia.

OHCHR. (2008). Report on indicators for promoting and monitoring the implementation of human rights. http://www2. ohchr.org/english/issues/indicators/docs/HRI.MC.2008.3_en.pdf

OHCHR. (2012a). Strengthening the United Nations Human Rights Treaty body system. Geneva: OHCHR. 
OHCHR. (2012b). Human rights indicators: A guide to measurement and implementation. Geneva: OHCHR.

Perlin, M. L. (2012). International Human Rights and Mental Disability law: When the silenced are heard. New York: Oxford University Press.

Ploton, V. (2017). The development of grading systems on the implementation of UN treaty body recommendations and the potential for replication to other UN human rights bodies. Geneva Academy of International Humanitarian Law and Human Rights Academic Platform Project. https://www.ishr.ch/sites/default/files/documents/tb_grading systems_their_replicability_to_other_un_hr_bodies.pdf

Popkin, B. M., Adair, L. S., \& Ng, S. W. (2012). Global nutrition transition and the pandemic of obesity in developing countries. Nutrition Reviews, 70(1), 3-21.

Potts, H., \& Hunt, P. (2008). Accountability and the right to the highest attainable standard of health. Essex: University of Essex.

Potts, H., \& Hunt, P. (2009). Participation and the right to the highest attainable standard of health. Essex: University of Essex.

Rosga, A., \& Satterthwaite, M. L. (2009). The trust in indicators: Measuring human rights. Berkeley Journal of International Law, 27, 253.

Røttingen, J.-A., Regmi, S., Eide, M., Young, A. J., Viergever, R. F., Ardal, C., .. Terry, R. F. (2013). Mapping of available health research and development data: What's there, what's missing, and what role is there for a global observatory? The Lancet, 382, 1286-1307.

UN General Assembly. (1948). Universal declaration of human rights.

UN General Assembly. (1966). International covenant on economic, social and cultural rights, G.A. Res. 2200A (XXI).

UN General Assembly. (2016). Status of the human rights treaty body system: Report of the secretary general, supplementary information. 18 July. A/71/118.

UN Secretary-General. (2005). Address to the UN commission on human rights. http://www.un.org/sg/STATEMENTS/ index.asp?nid $=1388$

WHO. (1946). Constitution of the World Health Organization.

WHO. (2002). 25 questions and answers on human rights. Geneva: WHO.

WHO. (2015). World report on ageing and health. Geneva: WHO.

WHO. (2017). Advancing the right to health: The vital role of law. Geneva: WHO.

Yamin, A. (2005). The right to health under international law and its relevance to the United States. American Journal of Public Health, 95(7), 1156-1161.

Yamin, A. (2008). Beyond compassion: The central role of accountability in applying a human rights framework to health. Health and Human Rights, 10(1), 45. 